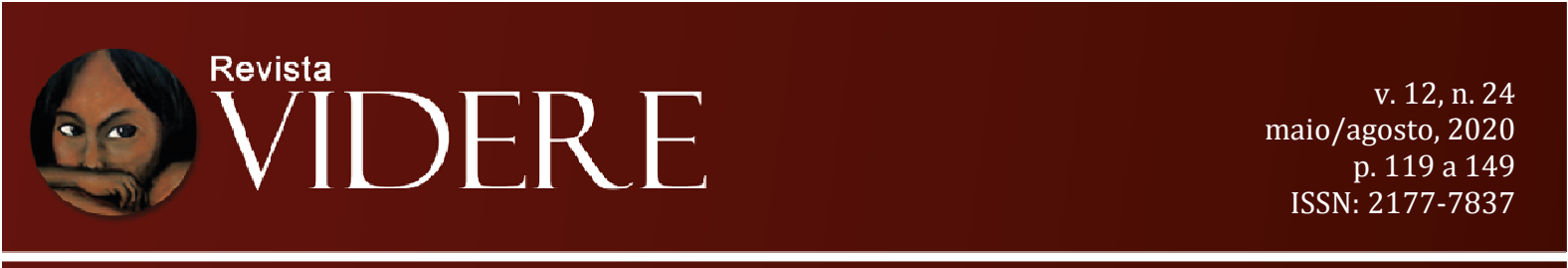

\title{
PATRIMONIALIDADE E CONTEMPORANEIDADE QUILOMBOLA: CONTROVÉRSIAS E DESAFIOS EM TORNO DO TOMBAMENTO DOS SÍTIOS DETENTORES DE REMINISCÊNCIAS HISTÓRICAS DOS ANTIGOS QUILOMBOS
}

\author{
PATRIMONIALIDAD Y CONTEMPORANEIDAD DE LOS QUILOMBOS: \\ CONTROVERSIAS Y DESAFÍOS EN TORNO DE LA PROTECCIÓN DE LOS \\ SITIOS POSEEDORES DE REMINISCENCIAS HISTÓRICAS DE LOS \\ ANTIGUOS QUILOMBOS
}

\begin{abstract}
Paulo Fernando Soares Pereira
Doutor em Direito, Estado e Constituição pela Universidade de Brasília (UnB), Brasil Mestre em Direito e Instituições do Sistema de Justiça pela Universidade Federal do Maranhão (UFMA), Brasil E-mail: paulofsp1983@gmail.com OrcID: http://orcid.org/0000-0001-6802-9035
\end{abstract}

\begin{abstract}
RESUMO: Incluídos na narrativa oficial do Estado Nação ( $\$ 5^{\circ}$ do art. 216), em processo relevantíssimo de resistência à escravidão do passado, os quilombos, tiveram a sua contemporaneidade afirmada no art. 68 do Ato das Disposições Constitucionais Transitórias ADCT, como fenômeno e sujeitos de direitos de um presente que ainda não soube lidar e compensar as dívidas históricas com aqueles que foram vítimas da opressão, da escravidão e do racismo do Estado colonial e imperial brasileiro. Para tanto, o trabalho tem como objetivo reafirmar a necessidade de reconhecimento e inclusão, nas políticas patrimoniais brasileiras, da resistência quilombola aos processos de opressão constituídos pela escravidão, os quais se perpetuam desde a Abolição da escravidão, em 1888, sem que o Estado Democrático de Direito, a partir de 1988, tenha dado e/ou efetivado as soluções jurídicas antirracistas capazes de lidar com a problemática. Utilizou-se a revisão crítica de literatura como metodologia.
\end{abstract}

PALAVRAS-CHAVE: Quilombos. Resistência. Patrimônio cultural. Contemporaneidade.

RESUMEN: Incluidos en la narrativa oficial del Estado Nación ( $\$ 5^{\circ}$ del artículo 216), en proceso relevante de resistencia a la esclavitud del pasado, los quilombos, tuvieron su contemporaneidad afirmada en el artículo 68 del ADCT - Acto de las Disposiciones Constitucionales Transitorias - ADCT, como fenómeno y sujetos de derechos de un presente que aún no ha sabido tratar y compensar las deudas históricas con aquellos que fueron víctimas de la opresión, de la esclavitud y del racismo del Estado colonial e imperial brasileño. De esa forma, el trabajo pretende reafirmar la necesidad de reconocimiento e inclusión, en las políticas patrimoniales brasileñas, de la resistencia quilombola a los procesos de opresión constituidos por la esclavitud, los cuales se perpetúan desde la Abolición de la 
esclavitud, en 1888, sin que el Estado Democrático de Derecho a partir de 1988, ha dado y / o efectivado las soluciones jurídicas antirracistas capaces de lidiar con la problemática. Se utilizó la revisión crítica de literatura como metodología.

PALABRAS CLAVE: Quilombos. Resistencia. Patrimonio cultural. Contemporaneidad.

\section{Introdução}

A Constituição Federal de 1988 estabelece que "ficam tombados todos os documentos e os sítios detentores de reminiscências históricas dos antigos quilombos" (art. $\left.216, \S 5^{\circ}\right)$. Apesar disso, junto ao Instituto do Patrimônio Histórico e Artístico Nacional IPHAN, apenas 02 (dois) sítios que se adequam a tal hipótese foram objetos de tombamento: a Serra da Barriga, antigo Quilombo dos Palmares, tombado em 1986, em União dos Palmares, em Alagoas (IPHAN, 1982b), e as reminiscências do antigo Quilombo do Ambrósio, tombado em 2002, em Ibiá, Minas Gerais (IPHAN, 1998c), ambos não habitados/ocupados, atualmente, por comunidades quilombolas. O primeiro caso é anterior à Constituição Federal, enquanto o segundo caso é posterior a 1988.

Por que outros quilombos não têm recebido, no plano administrativo, esse reconhecimento constitucional? Uma das hipóteses, no caso, diz respeito à rejeição que tem sido praticada em relação ao conceito de "quilombos históricos". Todavia, defendemos que há uma diferenciação constitucional entre o que está previsto no art. $216, \S 5^{\circ}$ da CF e o art. 68 do ADCT, naquilo que denominamos de patrimonialidade e contemporaneidade quilombola. Trata-se de uma dualidade, mas que, infelizmente, vem sendo tratada como um binarismo.

Os quilombos brasileiros, assim como as sociedades cimarronas, foram “comunidades concebidas”, isto é, organizadas à margem dos ordenamentos jurídicos vigentes $^{41}$, as quais em sua época, as autoridades coloniais e imperiais chegaram a declarar guerra, sendo que acabaram convertendo-se em sujeitos que desenvolveram novas e criativas formas de relação social entre os subalternizados, com o propósito de ser incluídos na sociedade de então (DE LA SERNA, 2010, p. 105).

Sob esse raciocínio, a questão inicial que deve ser levantada quando se trata de comunidades quilombolas é entender que a Constituição Federal de 1988 apresentou uma resposta constitucional aos silêncios, à negação e ao ocultamento da resistência quilombola, resposta, no entanto, que não menospreza o valor histórico do conceito de quilombo, que será

${ }^{41}$ A Lei de Terras, de 1850, promulgada em época na qual ainda vigia a escravização de pessoas negras, em seu art. $2^{\circ}$ e $6^{\circ}$, já sinalizava que não iria permitir qualquer forma de regularização dos territórios ocupados pelos quilombos. 
valorado sob o aspecto patrimonial, como se verá adiante. A noção comum que se tem de quilombos é permeada muito mais pela noção decorrente de sua disciplina jurídica, em tempos coloniais e imperiais, do que a sua própria noção histórica apresentada pela historiografia, ou seja, uma boa parcela das controvérsias que envolvem os conceitos decorre do ponto de partida da noção jurídica dos quilombos e não de sua realidade histórica apresentada até pela historiografia tradicional e reinterpretada pelos historiadores contemporâneos.

Entende-se, entretanto, que a Constituição Federal de 1988 deu uma resposta a esse historicismo jurídico, permitindo-se que a patrimonialidade quilombola não seja confundida com a sua contemporaneidade, apesar da correlação e complementariedade das questões, já que tratou tais institutos de maneiras diversas, conquanto os estudos relacionados à Antropologia e ao Direito tenham se centrado predominantemente no aspecto da contemporaneidade, pouco avançando no que diz respeito à patrimonialidade (PEREIRA, $2019 ; 2020)$.

\section{A Constituição e o rompimento com o pacto de silêncio em torno dos quilombos}

A Constituição Federal de 1988, após um século da abolição da escravidão (1888), a partir das lutas do movimento negro brasileiro, trata dos quilombos em dois momentos distintos, levando-se à compreensão de que as comunidades quilombolas, diante do fenômeno da modernidade, são sujeitos contemporâneos, estando inseridos na dialética de direitos assegurados pelo Estado Democrático de Direito e, consequentemente, pela cidadania (art. $1^{\circ}$, II, da CF). A Constituição Federal caminhou no sentido informado para Clóvis Moura (1993, p. 13), para quem estaria havendo uma revisão na história social do Brasil, particularmente no que diz respeito à importância dos quilombos na dinâmica da sociedade brasileira, pois eles se manifestaram nacionalmente como afirmação da luta contra o escravismo e as condições em que os escravizados viviam pessoalmente.

Nesse sentido, na lógica jurídica e constitucional, primeiro a Constituição Federal tratou de reconhecer os quilombos, no aspecto da patrimonialidade, denominadas de "reminiscências históricas dos antigos quilombos", como exemplos de protagonismo do que se denomina processo civilizador nacional, que nada mais é do que fixar tal protagonismo dentro do mito fundador do Estado-Nação, ao inseri-los na seção correspondente à cultura nacional. É importante registrar que antes de tratar dos quilombos em si, a Constituição Federal se preocupou em afirmar que as culturas indígenas e afro-brasileiras são construtoras 
do processo civilizador nacional, pois, além de dizer que "o Estado garantirá a todos o pleno exercício dos direitos culturais e acesso às fontes da cultura nacional, e apoiará e incentivará a valorização e a difusão das manifestações culturais" (art. 215, caput), reafirma que esse mesmo "Estado protegerá as manifestações das culturas populares, indígenas e afrobrasileiras, e das de outros grupos participantes do processo civilizatório nacional $\left(\S 1^{\circ}\right.$ do art. 215)". Posteriormente, a Emenda Constitucional $n^{\circ} 48 / 2005$ agregou novas diretrizes ao dispositivo constitucional:

Art. 215. O Estado garantirá a todos o pleno exercício dos direitos culturais e acesso às fontes da cultura nacional, e apoiará e incentivará a valorização e a difusão das manifestações culturais.

$\S 1^{\circ} \mathrm{O}$ Estado protegerá as manifestações das culturas populares, indígenas e afro-brasileiras, e das de outros grupos participantes do processo civilizatório nacional.

$\S 2^{\circ}$ A lei disporá sobre a fixação de datas comemorativas de alta significação para os diferentes segmentos étnicos nacionais.

$\S 3^{\circ} \mathrm{A}$ lei estabelecerá o Plano Nacional de Cultura, de duração plurianual, visando ao desenvolvimento cultural do País e à integração das ações do poder público que conduzem à:

I - defesa e valorização do patrimônio cultural brasileiro;

II - produção, promoção e difusão de bens culturais;

III - formação de pessoal qualificado para a gestão da cultura em suas múltiplas dimensões;

IV - democratização do acesso aos bens de cultura V - valorização da diversidade étnica e regional.

Note-se que apesar do dispositivo tratar "de outros grupos participantes do processo civilizatório nacional", dá-se ênfase às "manifestações das culturas populares, indígenas e afro-brasileiras" ${ }^{\text {, }}$, em uma tríade que ressalta o mito fundador da Nação baseado na formação indígena, europeia e africana.

Em seguida, a Constituição Federal, mais uma vez, ressalta o mito fundador, ao tratar do patrimônio cultural material e imaterial da Nação ao estabelecer que "constituem patrimônio cultural brasileiro os bens de natureza material e imaterial, tomados individualmente ou em conjunto, portadores de referência à identidade, à ação, à memória dos diferentes grupos formadores da sociedade brasileira", nos quais devem se incluir: "I - as formas de expressão; II - os modos de criar, fazer e viver; III - as criações científicas,

\footnotetext{
${ }^{42}$ Conforme parecerista anônimo(a), a(o) qual agradecemos a contribuição, a convivência pacifica é uma interpretação da ideia de democracia racial orientada pelos ensaios do Gilberto Freyre. O conflito, em termos acadêmicos, teria sido inserido por Darcy Ribeiro em seus estudos sobre a miscigenação brasileira e, posteriormente, introduzido por Florestan Fernandes em seus estudos sobre o negro e a sociedade de classes e a formação da nacionalidade, tendo, inclusive, este último, na Assembleia Constituinte, contribuído para fomentar tal debate junto com os representantes do movimento negro e indígena presentes na Câmara dos Deputados. Essa situação de conflitualidade no mito fundador é bem evidente com o tombamento previsto no art. $216, \S 5^{\circ}$, da CF.
} 
artísticas e tecnológicas; IV - as obras, objetos, documentos, edificações e demais espaços destinados às manifestações artístico-culturais; V - os conjuntos urbanos e sítios de valor histórico, paisagístico, artístico, arqueológico, paleontológico, ecológico e científico" (art. 216).

Para finalizar, a Constituição Federal, em 06 (seis) parágrafos complementares, após estabelecer o que constitui o patrimônio cultural brasileiro (art. 216), elenca as formas como tal patrimônio deve ser protegido, isto é, dá as diretrizes para que o Direito Administrativo possa atuar em favor daquilo que está no ideário do mito fundador do EstadoNação brasileiro.

$\S 1^{\circ}$ O Poder Público, com a colaboração da comunidade, promoverá e protegerá o patrimônio cultural brasileiro, por meio de inventários, registros, vigilância, tombamento e desapropriação, e de outras formas de acautelamento e preservação.

$\S 2^{\circ}$ Cabem à administração pública, na forma da lei, a gestão da documentação governamental e as providências para franquear sua consulta a quantos dela necessitem.

$\S 3^{\circ}$ A lei estabelecerá incentivos para a produção e o conhecimento de bens e valores culturais. $\S 4^{\circ}$ Os danos e ameaças ao patrimônio cultural serão punidos, na forma da lei.

$\S 5^{\circ}$ Ficam tombados todos os documentos e os sítios detentores de reminiscências históricas dos antigos quilombos.

$\S 6^{\circ}$ É facultado aos Estados e ao Distrito Federal vincular a fundo estadual de fomento à cultura até cinco décimos por cento de sua receita tributária líquida, para o financiamento de programas e projetos culturais, vedada a aplicação desses recursos no pagamento de:

I - despesas com pessoal e encargos sociais;

II - serviço da dívida;

III - qualquer outra despesa corrente não vinculada diretamente aos investimentos ou ações apoiados". [Grifou-se]

É didático lembrar que, inicialmente, eram apenas 05 (cinco) parágrafos, pois o $§$ $6^{\circ}$ foi incluído pela Emenda Constitucional $n^{\circ}$ 42/2003. Portanto, inicialmente, para os constituintes, o tombamento de "todos os documentos e os sítios detentores de reminiscências históricas dos antigos quilombos", teve um sentido especial, ao incluir na narrativa do próprio mito do Estado-Nação o protagonismo quilombola, proeminentemente negro, na formação do “processo civilizatório nacional” ( $§ 1^{\circ}$ do art. 215), assim como espécie de bens "portadores de referência à identidade, à ação, à memória dos diferentes grupos formadores da sociedade brasileira" (art. 216, caput). A essa primeira disciplina constitucional a respeito dos quilombos, pode-se denominar de patrimonialidade quilombola, a qual corresponde ao reconhecimento e inclusão da historicidade da resistência quilombola à opressão jurídica que 
foi a escravidão. O mesmo consta no Estatuto da Igualdade Racial (Lei $n^{\circ} 12.288 / 2010$ ), ao tratar da cultura:

Art. 18. É assegurado aos remanescentes das comunidades dos quilombos o direito à preservação de seus usos, costumes, tradições e manifestos religiosos, sob a proteção do Estado.

Parágrafo único. A preservação dos documentos e dos sítios detentores de reminiscências históricas dos antigos quilombos, tombados nos termos do $\S$

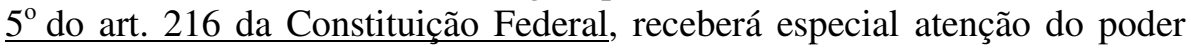
público.

Incluídos na narrativa oficial do Estado-Nação ( $\$ 5^{\circ}$ do art. 216), em processo relevantíssimo de resistência à escravidão do passado, apesar de ocultados, os quilombos, tiveram a sua contemporaneidade afirmada no art. 68 do Ato das Disposições Constitucionais Transitórias - ADCT, como fenômeno e sujeitos de direitos do presente, os quais devem ter tais direitos assegurados no presente e futuro, como forma de compensar as dívidas históricas com aqueles que foram vítimas da opressão, da escravidão e do racismo do Estado colonial, imperial e nacional. Portanto, este foi o segundo momento no qual a Constituição Federal tratou dos quilombos, ao dispor que "aos remanescentes das comunidades dos quilombos que estejam ocupando suas terras é reconhecida a propriedade definitiva, devendo o Estado emitir-lhes os títulos respectivos". Como já havia determinado o Decreto no 4.888/2003, isso foi reafirmado no Estatuto da Igualdade Racial (Lei $\mathrm{n}^{\circ}$ 12.288/2010), ao tratar do acesso à terra:

Art. 27. O poder público elaborará e implementará políticas públicas capazes de promover o acesso da população negra à terra e às atividades produtivas no campo.

Art. 28. Para incentivar o desenvolvimento das atividades produtivas da população negra no campo, o poder público promoverá ações para viabilizar e ampliar o seu acesso ao financiamento agrícola.

Art. 29. Serão assegurados à população negra a assistência técnica rural, a simplificação do acesso ao crédito agrícola e o fortalecimento da infraestrutura de logística para a comercialização da produção.

Art. 30. O poder público promoverá a educação e a orientação profissional agrícola para os trabalhadores negros e as comunidades negras rurais.

Art. 31. Aos remanescentes das comunidades dos quilombos que estejam ocupando suas terras é reconhecida a propriedade definitiva, devendo o Estado emitir-lhes os títulos respectivos.

Art. 32. O Poder Executivo federal elaborará e desenvolverá políticas públicas especiais voltadas para o desenvolvimento sustentável dos remanescentes das comunidades dos quilombos, respeitando as tradições de proteção ambiental das comunidades.

Art. 33. Para fins de política agrícola, os remanescentes das comunidades dos quilombos receberão dos órgãos competentes tratamento especial diferenciado, assistência técnica e linhas especiais de financiamento público, destinados à realização de suas atividades produtivas e de infraestrutura. 
Art. 34. Os remanescentes das comunidades dos quilombos se beneficiarão de todas as iniciativas previstas nesta e em outras leis para a promoção da igualdade étnica. [Grifou-se]

$\mathrm{O}$ art. 68 do ADCT vem logo em seguida à não cumprida promessa do Estado brasileiro de garantir os direitos territoriais aos povos indígenas, previsto no art. 67 do mesmo ADCT, que dispõe que "a União concluirá a demarcação das terras indígenas no prazo de cinco anos a partir da promulgação da Constituição". Assim, a leitura de tais dispositivos comprova que há um manifesto comando de inclusão de povos indígenas e afro-brasileiros na narrativa do Estado-Nação, através das políticas patrimoniais (patrimonialidade indígena e patrimonialidade quilombola), como reconhecimento do protagonismo dos mesmos na história, bem como a necessidade de que sejam assegurados os seus direitos territoriais, como reconhecimento da contemporaneidade de tais sujeitos, considerados como povos e comunidades tradicionais pelos instrumentos jurídicos internacionais ou nacionais ${ }^{43}$.

À diferenciação entre o que está previsto no art. $216, \S 5^{\circ}$, e ao que está previsto no art. 68 do ADCT, denominamos de patrimonialidade e contemporaneidade quilombola, a qual pode ser sintetizada no seguinte quadro, pois, juridicamente, há uma série de diferenciações entre o art. 216, $\S 5^{\circ}$, e art. 68 do ADCT da Constituição Federal:

\section{Quadro I - Comparação entre patrimonialidade e contemporaneidade quilombola}

\begin{tabular}{|c|c|c|}
\hline ELEMENTOS & $\begin{array}{c}\text { DISPOSITIVO } \\
\text { CONSTITUCIONAL }\end{array}$ & PROTEÇÃO \\
\hline $\begin{array}{c}\text { PATRIMONIALIDADE } \\
\text { (Narrativa histórica para fins de } \\
\text { reconstrução da memória } \\
\text { nacional do Estado-Nação) }\end{array}$ & $\begin{array}{l}\text { Art. 216. [...] } \$ 5^{\circ} \text {. "Ficam tombados } \\
\text { todos os documentos e os sítios } \\
\text { detentores de reminiscências } \\
\text { históricas dos antigos quilombos". } \\
\text { Reminiscências dão o sentido de } \\
\text { bens materiais e imateriais } \\
\text { (documentos e sítios históricos dos } \\
\text { antigos quilombos = quilombos } \\
\text { históricos). }\end{array}$ & $\begin{array}{l}\text { A proteção recai sobre os bens } \\
\text { materiais e imateriais } \\
\text { (representados pelas } \\
\text { resistências, lutas } \\
\text { negociações do passado), } \\
\text { podendo inclusive tal } \\
\text { dualidade ser totalmente } \\
\text { fundida. O objeto de proteção } \\
\text { constitucional é recuperar a } \\
\text { resistência quilombola, } \\
\text { silenciada/omitida/esquecida/o } \\
\text { cultada, na construção do mito } \\
\text { do Estado-Nação. }\end{array}$ \\
\hline $\begin{array}{l}\text { CONTEMPORANEIDADE/TE } \\
\text { RRITORIALIDADE } \\
\text { (Reconhecimento e inclusão da } \\
\text { contemporaneidade de sujeitos } \\
\text { históricos - comunidades } \\
\text { quilombolas -, com trajetória } \\
\end{array}$ & $\begin{array}{l}\text { ADCT. "Art. 68. Aos remanescentes } \\
\text { das comunidades dos quilombos que } \\
\text { estejam ocupando suas terras é } \\
\text { reconhecida a propriedade definitiva, } \\
\text { devendo o Estado emitir-lhes os } \\
\text { títulos respectivos". }\end{array}$ & $\begin{array}{l}\text { A proteção recai sobre os sujeitos } \\
\text { (comunidades dos quilombos) em } \\
\text { sua relação com a territorialidade, } \\
\text { objetivando a afirmação, o } \\
\text { reconhecimento e a inclusão das } \\
\text { identidades quilombolas, como }\end{array}$ \\
\hline
\end{tabular}

${ }^{43}$ São representativos, na esfera internacional, a Convenção 169 da Organização Internacional do Trabalho OIT, que trata dos Povos Indígenas e Tribais, ou nacionais, e, no plano nacional, o Decreto $\mathrm{n}^{\circ}$ 8.750/2016, que institui o Conselho Nacional dos Povos e Comunidades Tradicionais. 


\begin{tabular}{|c|c|c|}
\hline $\begin{array}{l}\text { ligada à escravidão e aos seus } \\
\text { efeitos após 1888) }\end{array}$ & $\begin{array}{l}\begin{array}{l}\text { Remanescentes dão o sentido de } \\
\text { sujeitos jurídicos } \\
\text { (pessoas/comunidades }\end{array} \\
\text { quilombos) enquanto sujeitos } \\
\text { históricos que tiveram a sua } \\
\text { contemporaneidade, reafirmada pela } \\
\text { territorialidade, reconhecida pela } \\
\text { Constituição. }\end{array}$ & $\begin{array}{l}\text { sujeitos contemporâneos de } \\
\text { direitos. } \\
\text { Aqui, o passado serve apenas } \\
\text { como um elo de ligação, pois a } \\
\text { Constituição exigiu precipuamente } \\
\text { "que estejam ocupando suas } \\
\text { terras", não lhes exigindo } \\
\text { nenhuma demonstração de } \\
\text { "enlatamento", "frigorificação" ou } \\
\text { "engessamento" de suas } \\
\text { identidades. }\end{array}$ \\
\hline
\end{tabular}

Essa diferenciação tem sido pouco trabalhada em termos acadêmicos, o que gera $o$

fato de se lidar com a questão de forma binária (excludente) e não dual (complementar). Os binarismos pressupõem que dois elementos se excluam mutuamente, devido à dominação de um sobre o outro, enquanto as dualidades pressupõem a complementação de ambos elementos (SEGATO, 2012). Assim, no mundo da modernidade, não há dualidade, mas binarismo e,

Enquanto na dualidade a relação é de complementaridade, a relação binária é suplementar, um termo suplementa o outro, e não o complementa. Quando um desses termos se torna 'universal', quer dizer, de representatividade geral, o que era hierarquia se transforma em abismo, e o segundo termo se converte em resto e resíduo: essa é a estrutura binária, diferente da dual. De acordo com o padrão colonial moderno e binário, qualquer elemento, para alcançar plenitude ontológica, plenitude de ser, deverá ser equalizado, ou seja, equiparado a partir de uma grade de referência comum ou equivalente universal. Isto produz o efeito de que qualquer manifestação da alteridade constituirá um problema, e só deixará de fazê-lo quando peneirado pela grade equalizadora, neutralizadora de particularidades, de idiossincrasias. $\mathrm{O}$ 'outro indígena', o 'outro não branco', a mulher, a menos que depurados de sua diferença ou exibindo uma diferença equiparada em termos de identidade que seja reconhecível dentro do padrão global, não se adaptam com precisão a este ambiente neutro, asséptico, do equivalente universal, ou seja, do que pode ser generalizado e a que se pode atribuir valor e interesse universal. Só adquirem politicidade e são dotados/as de capacidade política, no mundo da modernidade, os sujeitos - individuais e coletivos - e questões que possam, de alguma forma, processar-se, reconverter-se, transpor-se ou reformular-se de forma que possam se apresentar ou ser enunciados em termos universais, no espaço 'neutro' do sujeito republicano, onde supostamente fala o sujeito cidadão universal. Tudo o que sobra nesse processo, o que não pode converter-se ou equiparar-se dentro dessa grade equalizadora, é resto (SEGATO, 2012, p. 122-123).

Essa distinção ajuda a compreender que determinados conceitos ou temas são tratados de forma binária e não de maneira dual, como fez a Constituição ao tratar da temática quilombola. A disparidade entre a baixa quantidade de processos de tombamento (patrimonialidade) e a elevada quantidade de processos para reconhecimento e delimitação dos territórios (contemporaneidade) se deve ao fato da Constituição Federal, no caso do tombamento, ter restringido a proteção ao conceito de "quilombo histórico", pois determina "ficam tombados todos os documentos e os sítios detentores de reminiscências históricas dos 
antigos quilombos". Ocorre que isso vem sendo tratado como se fosse um binarismo e não como uma dualidade.

A expressão "sítios detentores de reminiscências históricas dos antigos quilombos" parece corresponder ao conceito tradicional de quilombo histórico e tem uso restrito ao tombamento para fins de ampliação da narrativa do Estado-Nação, mas esse mesmo quilombo histórico é múltiplo e diverso. O uso da terminologia de "quilombo histórico" pela Constituição Federal, no caso do tombamento, em nada prejudica os direitos das comunidades quilombolas previstos no art. 68 da ADCT, que têm seu alcance de proteção muito mais amplo, pois o conceito de comunidades quilombolas, neste último caso, vai além do "quilombo histórico". Aliás, na Ação Direta de Inconstitucionalidade no 3.239/DF, um dos fundamentos para se combater o Decreto $n^{\circ} 4.887 / 2003$ foi a ressignificação da conceituação de quilombo, pois o mesmo dispõe:

Art. $2^{\circ}$ Consideram-se remanescentes das comunidades dos quilombos, para os fins deste Decreto, os grupos étnico-raciais, segundo critérios de autoatribuição, com trajetória histórica própria, dotados de relações territoriais específicas, com presunção de ancestralidade negra relacionada com a resistência à opressão histórica sofrida.

$\S 1^{\circ}$ Para os fins deste Decreto, a caracterização dos remanescentes das comunidades dos quilombos será atestada mediante autodefinição da própria comunidade.

$\S 2^{\circ}$ São terras ocupadas por remanescentes das comunidades dos quilombos as utilizadas para a garantia de sua reprodução física, social, econômica e cultural.

$\S 3^{\circ}$ Para a medição e demarcação das terras, serão levados em consideração critérios de territorialidade indicados pelos remanescentes das comunidades dos quilombos, sendo facultado à comunidade interessada apresentar as peças técnicas para a instrução procedimental.

$\mathrm{O}$ art. 68 da ADCT, ao contrário do $\S 5^{\circ}$ do art. 216, não faz qualquer menção à expressão "reminiscências históricas dos antigos quilombos". Enquanto o art. 216, § 5', remete à patrimonialidade quilombola, ou seja, às resistências, lutas, negociações e bens materiais e imateriais do passado, o art. 68 do ADCT trata da contemporaneidade, tratando dos remanescentes das comunidades quilombolas, ou seja, refere-se aos grupos, sujeitos do presente ao estabelecer que "aos remanescentes das comunidades dos quilombos que estejam ocupando suas terras é reconhecida a propriedade definitiva, devendo o Estado emitir-lhes os títulos respectivos". A patrimonialidade e a contemporaneidade quilombola são duas formas de proteção distintas e complementares, as quais devem ser tratadas como hipótese de dualidade e não binarismo: 
a) A patrimonialidade, a primeira forma, refere-se ao passado dos quilombos, tratando dos documentos e sítios detentores das reminiscências dos "antigos quilombos", os quais devem ser objeto de identificação, já que o tombamento já recaiu constitucionalmente sobre os mesmos. Neste caso, a Constituição determina a proteção da memória e da história dos bens materiais e imateriais, no sentido de construção da narrativa de resistência dos quilombos ao sistema racista colonial e imperial que foi a escravidão, a qual a República inaugurada em 1889 insistiu em ignorar, ao promover a "construção burocrática do silêncio racial" (FISCHER; GRINBERG; MATTOS, 2018, p. 176). Determina, ainda, a Constituição que os documentos e sítios detentores das reminiscências dos antigos quilombos tenham a mesma proteção que os órgãos e entidades de proteção ao patrimônio cultural nacional vêm dando a outras questões, como, por exemplo, proteção ao patrimônio documental e bibliográfico $^{\mathbf{4 4}}$ de tradição luso-brasileira. Tais documentos, presentes em arquivos públicos e particulares, classificados ou não, devem ser objeto de proteção específica por parte dos órgãos e entidades de resguardo do patrimônio cultural brasileiro (Arquivo Nacional, IPHAN, FCP, IBRAM etc.), pois se trata da patrimonialidade documental.

b) A contemporaneidade é a segunda forma de proteção, que não exclui a primeira, tratando da proteção das comunidades remanescentes dos quilombos, que não necessitam, necessariamente, estar ocupando um território que coincida com um sítio com reminiscências de um antigo quilombo, pois durante mais de um século (1888 a 1988), o qual não houve disciplina jurídica sobre as comunidades quilombolas, houve transformação das referidas comunidades, as quais foram aumentando, à medida de sua reprodução física, social, econômica e cultural, nos termos reconhecido pelo $§ 2^{\circ}$ do art. $2^{\circ}$ do Decreto $\mathbf{n}^{\circ}$ 4.887/2003. A coincidência entre os sítios, para fins de reconhecimento de tombamento, dos quilombos históricos e contemporâneos pode ocorrer em muitos casos, mas não é necessária (o Quilombo dos Palmares e do Ambrósio foram dois sítios reconhecidos sem a existência de comunidades contemporâneas), surgindo daí a dificuldade das práticas patrimoniais, tendo em vista que o conceito de quilombo histórico foi praticamente expurgado das Ciências Sociais brasileiras, principalmente pela Antropologia ${ }^{45}$.

\footnotetext{
${ }^{44}$ A patrimonialidade documental e/ou bibliográfica possui forma de proteção específica, $c f$. ÁNGELES QUEROL, María. Manual de gestión del patrimonio cultural. Madrid: Akal, 2010, p. 285-300; MACARRÓN MIGUEL, Ana María. Conservación del patrimonio cultural: criterios y normativas. Madrid: Síntesis, 2008, p. 97-99 e 213-229.

${ }^{45}$ Nos momentos nos quais fizermos referências a esse expurgo pela Antropologia, principalmente, não se quer, de maneira, alguma desqualificar o trabalho dos antropólogos, mas apenas ressaltar que o conceito de "quilombos históricos" é como se fosse uma categoria ultrapassada para uma boa parcela desses cientistas sociais, os quais assumiram o protagonismo nas discussões em torno dos quilombos.
} 
A proteção dos "quilombos contemporâneos" recai sobre a territorialidade atual, isto é, a Constituição protege "as terras que estejam ocupando", pois, nesta última hipótese, é a própria contemporaneidade das comunidades quilombolas, com o conceito de quilombo ressignificado/ressemantizado pelo texto constitucional, não se exigindo, para fins do art. 68 do ADCT, que se trate de "quilombo histórico", isto é, "antigos quilombos", mas apenas que as comunidades sejam "remanescentes", isto é, que tenham um elo de ligação relacionado à resistência ao processo de escravidão (que é a presunção de ancestralidade), dado o caráter dinâmico (processos de negociações, constantes deslocamentos etc.) que sempre permeou os quilombos, dado que a população dos quilombos não era constituída apenas de escravizados fugitivos e de seus descendentes, convergindo para tais territorialidades outros tipos de trânsfugas, como soldados desertores, os perseguidos pela justiça secular e eclesiástica, ou aventureiros, vendedores, além de indígenas pressionados pelo avanço europeu; todavia, havia uma predominância dos africanos, de diferentes grupos étnicos, e seus descendentes, que, ali, administraram suas diferenças e forjavam novos laços de solidariedade, recriaram culturas (REIS, 95/96, p. 16; LINDOSO, 2011, p. 108).

\section{Quilombos como personagem coletivo da patrimonialidade da nação}

Discussões mais recentes sobre os quilombos têm sustentado a hipótese de tratalos como um personagem coletivo, como o primeiro intelectual negro, isto é, como uma inteligência historicamente coletiva, a mais longeva da historicidade brasileira (SIQUEIRA, 2018). Isso demonstra que há um campo não, só social, político e jurídico, mas, também, acadêmico a ser explorado. Porém, em que consiste essa possibilidade de novas investigações sociais em torno dos quilombos, isto é, o que os mesmos podem contribuir? Considerando que a sociedade brasileira, em sua complexidade, experimentou por quase 04 (quatro) séculos a escravização, é bastante oportuno que se investigue o seu contraponto: os quilombos, ainda mais quando se considera que a herança racista do sistema escravagista é estruturante das relações sociais no país. Portanto, não apenas como fenômeno que deu respostas a um sistema explicitamente racista, mas como símbolo de resistência a isso, o quilombo exsurge como representação da luta antirracista.

É enquanto caracterização ideológica que o quilombo inaugura o século XX. Tendo findado o antigo regime, com ele foi-se o estabelecimento como resistência à escravidão. Mas justamente por ter sido durante três séculos concretamente uma instituição livre, paralela ao sistema dominante, sua mística vai alimentar os anseios de liberdade da consciência nacional. [...] 
Durante sua trajetória o quilombo serve de símbolo que abrange conotações de resistência étnica e política. Como instituição guarda características singulares do seu modelo africano.

Como prática política apregoa ideais de emancipação de cunho liberal que a qualquer momento de crise da nacionalidade brasileira corrige distorções impostas pelos poderes dominantes. O fascínio de heroicidade de um povo regularmente apresentado como dócil e subserviente reforça o caráter hodierno da comunidade negra que se volta para uma atitude crítica frente às desigualdades sociais a que está submetida (NASCIMENTO, 2006, p. 122124).

Joel Rufino dos Santos (2015, p. 105-106) lembra que Palmares foi o caso extremo de marronage brasileiro, representando a chave da formação social escravista, que vigou por quatro séculos, isto é, 4/5 do nosso passado, abrindo uma janela sobre a decisiva dinâmica colonial, em que os estudos especializados parecem ter encalhado. É nesse sentido que o reconhecimento da patrimonialidade dos sítios remanescentes dos antigos quilombos é de importância jurídica essencial para a difusão da contribuição dos quilombos na construção de direitos, mesmo quando tais direitos se apresentam negados pela própria ordem jurídica: no passado, a liberdade; na atualidade, a igualdade, a inclusão etc.

A grande quantidade de quilombos nos períodos colonial e imperial fez Clóvis Moura (1993, p. 31) dizer que, se por um lado, isso demonstra, a existência de um sistema escravista de âmbito nacional, por outro, evidencia a participação do escravizado rebelde, no sentido de querer extinguir esse sistema, por ser o agente histórico e social no qual a contradição fundamental do escravismo se manifestava mais agudamente; assim, não se poderia deixar de ver o quilombo como um elemento dinâmico de desgaste das relações escravistas $^{46}$, o qual não teria sido uma manifestação esporádica de pequenos grupos de escravos marginais, desprovidos de consciência social, mas um movimento que atuou no centro do sistema nacional de forma permanente (MOURA, 1993, p. 31).

Em sentido semelhante, Edison Carneiro (2001; 2011, p. XLV) argumenta que o quilombo foi um acontecimento singular na vida nacional, seja qual for o ângulo encarado: como forma de luta contra a escravidão, estabelecimento humano, organização social ou reafirmação dos valores das culturas africanas, o quilombo se revela como um fato novo, único, peculiar, uma síntese dialética, representando um movimento contra o estilo de vida que os brancos lhe queriam impor; o quilombo mantinha a sua independência à custa das lavouras que os ex-escravizados haviam aprendido com os seus senhores e a defendia, quando necessário, com as armas de fogo dos brancos e os arcos e flechas dos indígenas; e, embora,

\footnotetext{
${ }^{46}$ Se o aquilombamento não teve um projeto de nova ordenação social, capaz de substituir o escravismo, em contrapartida, teve o potencial e dinamismo capazes de desgastar o sistema escravista e criar elementos de crise permanente em sua estrutura (MOURA, 1993, p. 14).
} 
em geral, contra a sociedade que oprimira os seus componentes, o quilombo aceitava muito dessa sociedade e foi, sem dúvida, um passo importante para a nacionalização da massa escravizada (CARNEIRO, 2011, p. XLV). Porém, o que restou dessas memórias e histórias quilombolas?

A patrimonialidade quilombola demonstra que a conquista de direitos é fruto das lutas políticas dos sujeitos interessados que superam os burocratismos das esferas formais e o negativismo da sociedade conservadora envolvente, daí o reconhecimento e a inclusão de "todos os documentos e os sítios detentores de reminiscências históricas dos antigos quilombos" na Constituição Federal, através da figura do tombamento (art. 216, $\S 5^{\circ}$ ). Portanto, para se resgatar a dívida que a sociedade brasileira tem para com o negro (exescravizado), há a necessidade básica de se mostrar, primeiramente, como ele vivia e reagia à condição de escravizado (MOURA, 1981, p. 12).

A proteção de "todos os documentos" se apresenta aparentemente "mais fácil", isto é, de melhor concretização/efetivação, não se tratando, atualmente, de uma política com fortes disputas jurídicas ${ }^{47}$. Em que pese a pouca efetividade e preocupação dos órgãos e entidades encarregados pelo cumprimento de tal dispositivo, há bastante tempo, há políticas de proteção a arquivos históricos no Brasil ${ }^{48}$, apesar de nem sempre se dar relevância aos documentos relacionados à escravidão e ao quilombismo, havendo valoração evidente dos documentos relacionados às elites coloniais, imperiais e republicanas. Todavia, Joel Rufino dos Santos (2015, p. 106 e 141) lembra que há um velho mito de que não se poderia fazer a história do negro por falta de documentos. O autor informa que, sobre Palmares, em arquivos portugueses e coloniais, há para mais de 5.000 documentos, após iniciativas como a do Projeto Resgate, fruto de acordo entre Brasil e Portugal, através do qual pesquisadores dos dois países, identificou, catalogou e digitalizou quase 150 mil documentos referentes ao passado colonial das antigas províncias brasileiras. Dessa forma, a fim de dar cumprimento ao comando constitucional, os órgãos e entidades encarregados da política arquivística e de proteção do patrimônio cultural já deveriam ter se articulado em torno de uma política de proteção aos documentos relacionados aos quilombos, tendo em vista que a Constituição Federal já os tombou, restando àqueles identifica-los e protegê-los.

\footnotetext{
${ }^{47}$ Edison Carneiro (2011, p. XXXV) lembra que não se dispõe de documentos fidedignos, minuciosos e circunstanciados a respeito de muitos dos quilombos que chegaram a existir no país, sendo que os nomes de vários líderes se perderam, já que os cronistas limitaram-se a exaltar as fadigas da tropa e a contar, sem detalhes, o desbarato final dos quilombolas.

${ }^{48}$ A Lei ${ }^{\circ} 8.159 / 91$ dispõe sobre a política nacional de arquivos públicos e privados e dá outras providências, estando regulamentada, atualmente, pelo Decreto $\mathrm{n}^{\circ} 4.073 / 2002$.
} 
Já em relação aos "os sítios detentores de reminiscências históricas dos antigos quilombos", as discussões das Ciências Sociais pouco avançaram após três décadas da Constituição Federal $^{49}$, sendo que apenas dois desses sítios tiveram o seu tombamento efetivado: Serra da Barriga, antigo Quilombo dos Palmares (aliás, antes da Constituição de 1988) e o Quilombo do Ambrósio, este último fruto do trabalho de pesquisadores da Universidade Federal de Minas Gerais - $\mathrm{UFMG}^{50}$.

A pouca representatividade patrimonial quilombola diante de sua forte presença nos tempos coloniais e imperiais se dá porque a prática patrimonial brasileira foi construída e dominada por critérios eurocentrados, de tradição luso-brasileira, mesmo quando tal prática se apresentou com um discurso que dizia reconhecer e exaltar os valores do Brasil ${ }^{51}$.

O fato é que, no processo de seleção dos bens culturais que seriam representativos da cultura brasileira - ou seja, que dariam materialidade à identidade nacional -, o lugar de destaque absoluto coube à arte e às edificações ligadas diretamente à colonização portuguesa, já que o patrimônio cultural a ser preservado era entendido como patrimônio material revestido de caráter monumental. Como as matrizes indígena e africana não apresentavam edificações que testemunhassem suas contribuições, justificava-se, aos olhos dos gestores, que o foco deveria estar nos exemplares materiais da civilização e da arte europeias (GURAN, 2017, p. 215).

Nas últimas décadas, houve um significativo avanço em relação ao reconhecimento da patrimonialidade negra ${ }^{52}$, mas que ainda não chegou na única hipótese de tombamento previsto na própria Constituição Federal, que é o tombamento de todos os documentos e sítios detentores de reminiscências históricas dos antigos quilombos, pois os processos aos quais se referem tais hipóteses continuam sem definição junto ao IPHAN, o

\footnotetext{
${ }^{49}$ Cf. VAZ, Beatriz Aciolly. Os grilhões do patrimônio: reflexões sobre as práticas do IPHAN relacionadas aos quilombos. Revista CPC: Centro de Preservação Cultural, n 17, p. 35-46, nov. 2013/abr. 2014. A autora critica a posição de tombamento apenas dos "quilombos históricos", mas não dá pistas de como se efetivaria o tombamento dos quilombos contemporâneos, em quantidade muito maior do que aqueles, já que, em seus processos de negociação, passaram por diversas transformações e se multiplicaram, a fim de sobreviver ao esquecimento de quaisquer políticas públicas que lhes alcançassem. Não foi em vão que os constituintes tiveram que cindir a patrimonialidade da contemporaneidade quilombola. Caso a contemporaneidade estivesse fundida na patrimonialidade, verdadeiramente, ter-se-ia que "engessar", "enlatar", "frigorificar" a noção dos quilombos contemporâneos (PEREIRA, 2019; 2020).

${ }^{50}$ A UFMG possui um laboratório de Arqueologia, o qual muito tem contribuído para as pesquisas relacionadas à cultura material da escravidão no Brasil. $C f$. SINGLETON, Theresa A. Reflexões sobre a arqueologia da diáspora africana no Brasil. Vestígios: Revista Latino-Americana de Arqueologia Histórica, vol. 7, no 1, p. 211219, jan./jun. 2013; SOUZA, Marcos André T. de. Introdução: arqueologia da diáspora africana no Brasil. Vestígios: Revista Latino-Americana de Arqueologia Histórica, vol. 7, nº 1, p. 9-19, jan./jun. 2013.

${ }^{51} C f$. CHUVA, Márcia. Fundando a nação: a representação de um Brasil barroco, moderno e civilizado. Topoi, vol. 4, no 7, p. 313-333, jul./dez. 2003.

${ }^{52}$ Cf. GURAN, Milton. Sobre o longo percurso da matriz africana pelo seu reconhecimento patrimonial como uma condição para a plena cidadania. Revista do Patrimônio, no 35, p. 213-226, 2017; SERRA, Ordep. Monumentos negros: uma experiência. Afro-Ásia, no 33, p. 169-205, 2005.
} 
qual ainda não conseguiu articular uma política patrimonial para os mesmos ${ }^{53}$. Quando se verifica a cartografia ou geografia dos quilombos históricos ${ }^{54}$, percebe-se o quanto a memória quilombola está ocultada/invisibilizadas/esquecida.

Ora, tratando-se o tombamento quilombola de hipótese única prevista na Constituição Federal, esperava-se maior esforço em relação a tal temática, pois o seu esquecimento e "não decisão" dão indicativos da prática do racismo institucional e cultural em relação às comunidades quilombolas, posturas que não se mostram condizentes com as práticas que devem permear as ações do Estado.

Nesse contexto, e seguindo a tendência patrocinada pela própria UNESCO, com o não raras vezes criticado $^{55}$ projeto $A$ Rota dos Escravos ${ }^{56}$, de reconhecimento da patrimonialidade diaspórica, a patrimonialidade quilombola abre novas fissuras no monismo cultural da narrativa do Estado-Nação, sendo fundamental considerar o direito humano aos patrimônios culturais que se situem sob o olhar do pluralismo e da interculturalidade, que critica o patrimônio singular, entendido desde a ideia de nação monocultural, identificada na matriz da colonialidade do poder, do saber e do ser que o atravessa e que dá conta apenas de direitos mais específicos, de indivíduos e grupos em torno dos processos de gestão patrimonial (COLOMBATO; MEDICI, 2016, p. 69).

Além disso, acredita-se que o pouco avanço dos estudos em torno da patrimonialidade quilombola seja, contraditoriamente, um efeito da interpretação jurídica que se deu a respeito da contemporaneidade das comunidades quilombolas, prevista no art. 68 do

\footnotetext{
${ }^{53}$ No ano de 2017, o IPHAN lançou uma proposta, através de consulta pública, de uma política de patrimônio material, a qual trata do patrimônio quilombola, tendo como novidade a instrução dos processos pela Fundação Cultural Palmares e uma maior articulação entre as referidas entidades, inclusive com o INCRA.

${ }^{54}$ Discussões em torno de uma geografia e cartografia dos quilombos podem ser encontradas em: ANDRADE, Manuel Correia de. Geografia do quilombo. In: MOURA, Clóvis (org.). Os quilombos na dinâmica social do Brasil. Maceió: EDUFAL, 2001, p.75-87; ANJOS, Rafael Sanzio A. dos. Cartografia da diáspora África-Brasil. Revista da ANPEGE: Associação Nacional de Pesquisa e Pós-Graduação em Geografia, vol. 7, no 1, p. 261274, out. 2011; MOURA, Clóvis. Os quilombos e a rebelião negra. São Paulo: Brasiliense, 1981, p. 22-33; SANTANA FILHO, Diosmar Marcelino de. A geopolítica do Estado e o território quilombola no século XXI. Jundiaí: Paco Editorial, 2018, p. 100-103; SANTOS, Ynaê Lopes dos. História da África e do Brasil afrodescendente. Rio de Janeiro: Pallas, 2017, p. 224-234.

${ }_{55}$ As críticas apontam um imperialismo cultural: $c f$. AGIER, Michel. La antropologia de las identidades en las tensiones contemporâneas. Revista Colombiana de Antropología, vol. 36, p. 6-17, ene./dic. 2000; AGIER, Michel. Distúrbios identitários em tempos de globalização. Mana, vol. 7, nº 2, p. 7-33, 2001; AGIER, Michel; QUINTÍN, Pedro. Política, cultura y autopercepción: las identidades en cuestión. Estudos Afro-Asiáticos, ano $25, \mathrm{n}^{\circ} 1$, p. $23-41,2003$.

${ }^{56}$ Nesse sentido, a UNESCO, em julho de 2017, reconheceu o Cais do Valongo, no Rio de Janeiro, como Patrimônio Cultural da Humanidade. "Pela sua excepcionalidade e valor simbólico, já reconhecidos pelo Projeto Rota do Escravo da Unesco em 2013, o Cais do Valongo é considerado o mais contundente lugar de memória da chamada diáspora africana fora do seu continente de origem, testemunho material irretorquível do tráfico atlântico de africanos escravizados, hoje justamente considerado crime contra a humanidade, convém sempre relembrar. É um sítio de memória sensível, daqueles que se reportam a um evento reconhecido como extremamente doloroso por toda a humanidade, como Auschwitz-Bierkenau ou Hiroshima, que precisam ser lembrados para impedir que voltem a acontecer" (GURAN, 2017, p. 225).
} 
ADCT, que avançou significativamente, mas que, por outro lado, tentou desvencilhar-se da ideia de "quilombos históricos" $"$. Do ponto de vista da interpretação constitucional, a preocupação é infundada, pois a disciplina da patrimonialidade e contemporaneidade é distinta, apesar de complementares. Após a decisão do Supremo Tribunal Federal - STF, na ADI $n^{\circ}$ 3239, em 2018, como importante decisão em favor dos territórios quilombolas, espera-se que as discussões em torno da conquista e efetivação de outros direitos sejam levadas adiante, como é o caso dos direitos culturais, superando-se a já tradicional discussão apenas em relação à fundiariedade, superando-se os equívocos decorrentes de disputas sociais, políticas, judiciais e, até mesmo, acadêmicas em torno da temática quilombola, muitas das quais fomentadas pelo próprio Estado ${ }^{58}$.

Nas comunidades quilombolas, após regulamentações oficiais, a reorganização política local teve como um de seus traços marcantes o uso das manifestações culturais para produzir e comunicar significados capazes de comprovar a remanescência e identidade quilombola, uma condição colocada pelo Estado para o acesso às políticas públicas (CUNHA; ALBANO, 2017, p. 156).

A patrimonialidade quilombola, ao reconhecer e incluir a história de resistência dos quilombos no panteão do patrimônio cultural nacional (art. 216, § 5º da CF), dá sustentáculo ao também reconhecimento e inclusão da contemporaneidade das comunidades quilombolas por direitos fundiários (art. 68 do ADCT), o qual necessitou de ressignificação e ressemantização por parte dos intérpretes, pois a redação constitucional, seja na patrimonialidade ou contemporaneidade, já nasceu ressignificada e ressemantizada, já que a Constituição Federal em momento algum tratou das comunidades quilombolas de maneira "frigorificada", "enlatada", "engessada" ou "fossilizada". Contrariamente, a Constituição tratou de reevidenciar o elo da resistência escrava anterior a 1888 e as comunidades "remanescentes" desse processo opressivo, as quais estiveram, durante um século, colocadas em um "não lugar jurídico", já que, entre 1888 a 1988, juridicamente, ingressavam na

\footnotetext{
57 Sobre as razões e interesses políticos que levaram a Assembleia Nacional Constituinte a separar patrimonialidade (art. 216, $\S 5^{\circ}$ ) da contemporaneidade quilombola (art. 68 do ADCT), $c f$. CAMPOS, Yuseff D. Salomão de. Desafios propostos pela Constituição de 1988 ao patrimônio cultural. Revista do Patrimônio, no 35, p. 203- 212, 2017.

${ }^{58}$ Os quilombos em Alcântara, no Maranhão, constituem um exemplo, tendo em vista que o processo de conflitualidade, com a instalação da Base Aeroespacial, foi fomentado pelo próprio Estado brasileiro, o qual nunca conseguiu dar uma solução para aquelas comunidades, $c f$. ALMEIDA, Alfredo Wagner Berno de et al. (org.). Quilombolas: reivindicações e judicialização dos conflitos. Manaus: UEA Edições, 2012; ALMEIDA, Alfredo Wagner Berno de; ANJOS, Leonardo dos et al. Direitos e mobilização: a luta dos quilombolas de Alcântara contra a base espacial. Rio de Janeiro: Casa 8, 2016; COELHO, Leonardo Oliveira Silva. Terras de sustança: resistência quilombola e estratégias de reapropriação de território em Alcântara. São Luís: EDUFMA, 2017; SOUZA FILHO, Benedito. Os novos capitães do mato: conflitos e disputa territorial em Alcântara. São Luís: EDUFMA, 2013.
} 
categoria de comunidades rurais/camponesas, sem que a sua resistência e racialidade fossem levadas em conta pelas políticas do Estado. Sobre isso, Flávio dos Santos Gomes (2006, p. 290), ao tratar dos quilombos amazônicos, recorda que,

Não só para a Amazônia, mas também outras regiões do Brasil pós-colonial e também em áreas da Colômbia e Venezuela, talvez esta tenha sido uma das principais características da formação de comunidades de escravos fugidos e a transformação em micro sociedades camponesas no pós emancipação, incluindo aí a migração permanente. Ao contrário de mocambos grandes e mais estáveis como muitos do Brasil Colônia do século XVIII, surgiam pequenos quilombos formados de grupos de fugitivos, que se refaziam e se desmanchavam em pequenas comunidades organizadas por grupos de parentesco e companheiros de fugas. São estas algumas das narrativas que emergem na documentação sobre quilombos em várias partes da Amazônia. Grupos de fugitivos - muitos até com chefias e estruturas organizativas mais complexas - itinerantes e conectados com vilas, povoados, fazendas em termos de trocas mercantis.

No entanto, ainda é prevalecente nas Ciências Sociais, após fortes disputas entre a História e a Antropologia ${ }^{59}$, uma ideia segundo a qual tratar dos antigos quilombos, sob a perspectiva da patrimonialidade, histórica ou arqueológica, é uma tentativa de se essencializar a discussão em torno dos quilombos contemporâneos. Dessa forma, Carlos Eduardo Marques (2009, p. 350) diz que:

Em resumo, ao se essencializar esses patrimônios, perde-se a sua principal característica, a vivacidade, um bem em movimento constante, dinâmico e vivo, o que ele é, e o transforma em um objeto de desejo insaciável, a ser rememorado a partir de uma definição externa a despeito de suas especificidades. Na versão ressignificada, o termo remanescente de quilombo exprime um direito a ser reconhecido em suas especificidades e não apenas um passado a ser rememorado. Ele é a voz da cidadania autônoma destas comunidades (MARQUES, 2009, p. 350).

Em sentido semelhante, Valdélio dos Santos Silva (2000, p. 267), ao tratar da aplicação do art. 68 do ADCT ao quilombo Rio das Rãs, critica a essencialização passada dos quilombos por parcela da historiografia.

Um óbice, por exemplo, para a não aplicação do referido artigo é o fato de que sua interpretação está calcada na ideia de quilombo concebida a partir de preceitos jurídicos da legislação colonial/escravista. É nessa legislação que os historiadores se inspiraram para conceituar quilombo e para a qual convergem as

\footnotetext{
${ }^{59}$ Richard Price (2003, p. 393) já havia notado tal disputa entre antropólogos e historiadores. Ainda, $c f$. FIABANI, Adelmir. Mato, palhoça e pilão: o quilombo, da escravidão às comunidades remanescentes [15322004]. São Paulo: Expressão Popular, 2012, p. 28-30 e 347-410, com críticas ao papel da Antropologia em relação aos quilombos.
} 
argumentações contrárias à aplicação da atual norma constitucional [...] Daí ser necessário romper com os postulados nos quais certa historiografia se baseou para construir a noção de quilombo no Brasil e que, hoje, servem de referência para fundamentar o discurso jurídico.

Apesar dessas críticas, do ponto de vista constitucional, há questões distintas que não têm sido observadas por parcela dos pesquisadores: patrimonialidade e contemporaneidade das comunidades quilombolas. A discussão da primeira em nada compromete o reconhecimento e a inclusão de direitos da segunda, sendo tal binarismo fruto de uma perspectiva científica na qual sempre há que se escolher o caminho mais racional que, no caso, seria o reconhecimento dos direitos territoriais das comunidades quilombolas contemporâneas, ressignificadas/ressemantizadas pelas Ciências Sociais, em vez da adoção de uma ideia "frigorificada", de "pedra e cal" dos quilombos do passado, ideia geralmente atribuída à História. Mais uma vez, apresenta-se a crítica de Carlos Eduardo Marques (2009, p. 352), para quem,

É dessa forma estrutural-histórica que deve ser entendida a categoria remanescentes de quilombos, como um ente vivo, para que possa cumprir o fim a que se propôs e sua ordem constitucional: o reconhecimento da propriedade territorial definitiva e a emissão de seus respectivos títulos. Torna-se necessária a ruptura com o modelo de "pedra e cal" e a elaboração de um novo conceito socioantropológico e jurídico para os remanescentes das comunidades de quilombo, uma vez que o art. 68 do ADCT não apenas reconheceu o direito que as comunidades remanescentes de quilombos possuem sobre as terras que ocupam, como também criou tal categoria política e sociológica: embora os grupos étnicos beneficiados pela legislação já existissem, não se denominavam com base na categoria remanescentes de quilombos.

Trata-se de uma interpretação binária, competindo ao Direito Constitucional, como ramo especializado das Ciências Sociais, mediar, e ao Direito administrativo efetivar a disputa entre Antropologia e História, a fim de não se comprometer os direitos culturais das comunidades quilombolas. Em verdade, em vez de binarismo, trata-se de uma dualidade, a qual pressupõe complementariedade e diálogo ${ }^{60}$. Em processos judiciais que discutem o direito à territorialidade quilombola, é comum historiadores defenderem a noção de quilombo histórico enquanto os antropólogos os quilombos contemporâneos, como se fossem água e azeite, os quais não se misturam. No caso, a base das argumentações para a não aplicação do art. 68 do ADCT retoma o arcabouço jurídico colonial, que definia quilombo como grupos de

\footnotetext{
${ }^{60}$ Sobre o confronto entre binarismo e dualidade, $c f$. SEGATO, Rita L. Gênero e colonialidade: em busca de chaves de leitura e de um vocabulário descolonial. E-cadernos CES, nº 18, p. 106-131, 2012.
} 
escravizados que, à margem das leis existentes, fugiam e se embrenhavam nas matas para saquear, roubar e matar administradores e proprietários de fazendas; tal noção, ainda hoje, baliza e estrutura os argumentos legais dos que advogam contra os interesses das comunidades (SILVA, 2000, p. 266-267). A disputa se mostra equivocada, devendo ser mediada pelo Direito, já que a Constituição Federal evidencia que são questões diferentes, apesar de permeadas pela dualidade e não pelo binarismo, ou seja, nenhuma interpretação sobre a questão pode levar à redução de direitos das comunidades quilombolas, mas apenas à sua ampliação, já que os dispositivos, em ambos os casos, constituem-se em medidas antirracistas de afro reparação constitucional ${ }^{61}$.

\section{Contemporaneidade quilombola}

Explicitada a noção de patrimonialidade (art. 216 , $\S 5^{\circ}$, da $C F$ ), não se pode esquecer da importância da contemporaneidade quilombola, temática com bastantes estudos no Brasil e prevista no art. 68 do ADCT. O que representaram camponeses e comunidades rurais no Brasil? Paradoxalmente, a forma camponesa mais conhecida para o período da escravidão são as comunidades de escravizados fugidos, sendo que quilombos e mocambos são as denominações históricas no Brasil colonial e pós-colonial para grupos de fugitivos e tendo mais recentemente as terminologias "reminiscências" e "remanescentes" surgido como categorias jurídicas previstas no art. 216, § 5 , e art. 68 do ADCT da Constituição de 1988 (GOMES, 2012, p. 375-376).

No processo de ressemantização, os quilombos foram cada vez mais assumindo a terminologia de quilombolas ou comunidades quilombolas após $1988^{63}$, a fim de expurgar qualquer conceito essencialista. Sobre isso, Flávio dos Santos Gomes (2012, p. 376) informa

\footnotetext{
${ }^{61}$ As medidas constitucionais parecem se adequar ao que vem sendo chamado de etnorreparação ou afrorreparação, $c f$. LAO-MONTES, Agustín. Sin justicia étnico-racial no hay paz: las afro-reparaciones en perspectiva histórico-mundial. In: MOSQUERA ROSERO-LABBÉ, Claudia; BARCELOS, Luiz C. Afroreparaciones: memorias de la esclavitud y justicia reparativa para negros, afrocolombianos y raizales. Bogotá: UNAL, 2007, p. 131-154; MATTOS, Hebe. Ciudadanía, racialización y memoria del cautiverio en la historia de Brasil. In: MOSQUERA ROSERO-LABBÉ, Claudia; BARCELOS, Luiz C. Afro-reparaciones: memorias de la esclavitud y justicia reparativa para negros, afrocolombianos y raizales. Bogotá: UNAL, 2007, p. 131-152; MOSQUERA ROSERO-LABBÉ, Claudia; LAÓ-MONTES, Agustín; RODRÍGUEZ GARAVITO, César. Debates sobre ciudadanía y políticas raciales en las Américas Negras. Bogotá: UNAL, 2010; RODRÍGUEZ GARAVITO, César; LAM, Yukyan. Etnorreparaciones: La justicia colectiva étnica y la reparación a pueblos indígenas y comunidades afrodescendentes en Colombia. Bogotá: Dejusticia, 2011.

${ }^{62}$ Sobre a diferença entre reminiscências e remanescentes, $c f$. BORBA, Fernanda Mara. Entre reminiscências e remanescente: a presença e a ausência do passado em torno do quilombo no Brasil. Anais do III Seminário Internacional História do tempo presente, UDESC, Florianópolis, 2017, p. 1-13.

${ }^{63} \mathrm{Cf}$. MARQUES, Carlos Eduardo. De quilombos a quilombolas: notas sobre um processo histórico-etnográfico. Revista de Antropologia, vol. 52, nº 1, p. 339-374, 2009.
} 
que considerando tempos e espaços, entre os quilombos históricos, não raramente fossilizados na legislação colonial ou em determinadas interpretações historiográficas, e as comunidades remanescentes, “descobertas" por antropólogos, flagradas em etnografias e emergentes no discurso dos movimentos sociais, faltou conhecer os processos históricos da constituição de um campesinato negro e as formas de culturas dos mundos rurais.

Sob o aspecto de formas camponesas, os quilombos não foram cenários exclusivos de escravos e africanos. Assunto ainda pouco conhecido no Brasil, muitos quilombos se formaram conjuntamente com indígenas (escravizados ou livres fugidos de aldeamentos), africanos e crioulos. Sabemos que os fatores geográficos interferiram na localização e estabilidade de algumas comunidades. Para além dos conflitos e confrontos - negros fugidos aliaram-se a grupos indígenas, formando comunidades (GOMES, 2012, p. 379).

É interessante que, para o passado, os quilombos foram definidos, na legislação da época e determinada interpretação historiográfica, somente como unidade da resistência escrava, enquanto para o presente, as denominadas comunidades remanescentes aparecem muitas vezes nas etnografias como espaços da reminiscência cultural, quase fósseis; as atuais comunidades negras rurais, valendo dizer que muitas não são necessariamente originadas dos quilombos históricos, mas combinadas entre eles e complexos espaços agrários (vilas, feiras, entrepostos de trocas mercantis etc.) conectados por vários setores rurais na escravidão e na pós-abolição, para algumas definições jurídicas e tipologias das políticas públicas não são consideradas povos da floresta, não são alinhados como trabalhadores rurais e mesmo contempladas na pauta contemporânea dos movimentos sociais de luta pela terra, como o Movimento dos Trabalhadores Rurais Sem Terra - MST e outros (GOMES, 2012, p. 391).

Nesse sentido, Richard Price (1999b, p. 23) informa que a interpretação que foi dada ao conceito ressignificado e ressemantizado de quilombo, ao tratar o art. 68 do ADCT, é uma mínima porém significativa rachadura no monólito brasileiro de direito de propriedade, pois remanescente de quilombo teria se tornado uma categoria reconhecida, ainda que numericamente minúscula, ao lado de populações indígenas e das grandes massas de semterra, na luta geral pela redistribuição de terras no Brasil, que seria a mais desigual das sociedades modernas.

Esse processo de ressignificação e ressemantização das terminologias constitucionais a respeito dos quilombos é importante porque não se trata de mero preciosismo linguístico/hermenêutico, tratando-se de verdadeiro processo político de 
negociação de direitos em disputa ${ }^{64}$. Através disso, consegue-se reconhecer os quilombolas como comunidades contemporâneas, mesmo diante de seu modo de vida tradicional ${ }^{65}$. A tradicionalidade $^{66}$, depois da Constituição de 1988, passou a constituir um elemento que leva à uma reflexão mais detida da dimensão política adquirida pela expressão; contra a despolitização positivista que via o tradicional como algo extemporâneo, como algo do passado, esse tradicional tem que ser interpretado, tendo que passar por um processo de ressignificação, o qual implica numa politização dessa forma de conhecimento, separando-se, por isso, do imemorial, que era um recuo a uma origem indefinida; as terras imemoriais, que constituíam a figura jurídica anterior, eram um recuo indefinido; por outro lado, o tradicional é passível de datação (ALMEIDA, 2005b, p. 2).

Assim, o sentido dessa contemporaneidade está em reconhecê-las como comunidades que não estão deslocadas no fator tempo, como se fossem figuras do passado, estando estabelecidas no presente com a mesma relevância, por exemplo, das populações urbanas ou de quaisquer outras: tratam-se de comunidades do presente (ALMEIDA, 2002, p. 53). O reconhecimento de sua contemporaneidade leva o sistema jurídico, a partir das lutas sociais, a protegê-las de quaisquer pretensões engessantes ou de discursos que tentem acusálas de constituírem obstáculos aos processos de "desenvolvimento" ou da ideologia do "progresso", retóricas bastantes comuns nos discursos que permeiam o Estado-Nação. Portanto, qualquer processo de "desenvolvimento" deve reconhecer e lidar com o pressuposto de que se tratam de comunidades contemporâneas marcadas pela tradicionalidade de seu modo de vida, de modo algum inferior aos modos de vida hegemônicos.

Nesse contexto, chama atenção o quanto as comunidades quilombolas, após 1988, tiveram que ocupar um espaço de luta e defesa dos seus direitos, já que seus territórios

\footnotetext{
${ }^{64}$ Antes da proposição e julgamento da ADI no 3239, o Projeto de Lei no 129 , de 1995 (nº $3.207 / 97$ na Câmara dos Deputados), que pretendia regulamentar o direito de propriedade das terras das comunidades remanescentes dos quilombos e o procedimento da sua titulação de propriedade imobiliária, na forma do art. 68 do ADCT, foi vetado integralmente pela Presidência da República, através da mensagem no 370 , de 13 de maio de 2002. Sobre tais disputas, $c f$. ARRUTI, José Maurício Andion. As comunidades negras rurais e suas terras: a disputa em torno de conceitos e números. Dimensões, vol. 14, p. 243-267, 2002.

65 A questão da contemporaneidade quilombola é abordada especificamente em alguns trabalhos: $c f$. MARQUES, Carlos Eduardo; GOMES, Lílian. A Constituição de 1988 e a ressignificação dos quilombos contemporâneos. Revista Brasileira de Ciência Sociais, vol. 28, no 81, p. 137-255, fev. 2013; SOUSA, José Reinaldo Miranda de. Quilombos (palenques), terras de pretos: identidades em construção. Revista Brasileira do Caribe, vol. XI, no 22, p. 33-57, jan./jun. 2011.

${ }^{66}$ Tradicionalidade é uma categoria bastante trabalhada, cf. BENATTI, José Heder et. al. Populações tradicionais e o reconhecimento de seus territórios: uma luta sem fim. $\mathbf{7}^{\mathbf{0}}$ Encontro Nacional da Associação Nacional de Pós-Graduação e Pesquisa em Ambiente e Sociedade - ANPPAS, p. 1-19, 2015; SHIRAISHI NETO, Joaquim. A particularização do universal: povos e comunidades tradicionais face às declarações e convenções internacionais. In: Direitos dos povos e das comunidades tradicionais no Brasil: declarações, convenções, internacionais e dispositivos jurídicos definidores de uma política nacional. Manaus: UEA, 2007, p. 25-52.
} 
passaram a constituir espaços de pretensão para a expansão do sempre insatisfeito agronegócio e de outros setores que veem suas terras uma fonte de cobiça. As identidades e os modos de vida das comunidades quilombolas têm sido objeto de questionamentos dos mais diversos tipos, suas falas e discursos são ignorados por um sistema econômico, social, político e jurídico dominado por uma hegemonia e lógica de privilégios que despreza a diferença, ainda mais quando tal diferença está permeada pela predominância racial negra, o que evidencia o racismo institucional e cultural brasileiro.

Assim, afinal, qual o significado constitucional da contemporaneidade dos remanescentes de quilombos? Flávio dos Santos Gomes (2012, p. 392) argumenta que o debate atual sobre as comunidades negras rurais é complexo, não cabendo definições ahistóricas, etnografias improvisadas e muito menos há espaço para certezas e verdades, absolutas e definitivas, pois estão em jogo lutas seculares pela terra ${ }^{67}$, tradições de uso e manejo dela, direitos constitucionais, reconhecimento do passado, formas de políticas públicas afirmativas e de reparação histórica, havendo muito mais coisas, de todos os lados e interesses; sendo a definição de remanescentes de quilombos tanto abrangente como operacional, muitas comunidades enfrentam problemas de reconhecimento nos órgãos públicos e também de respeito (ou a falta de) quanto às demarcações não obedecidas por setores agrários interessados em suas terras e territórios; há morosidade nas titulações definitivas das terras e também alguns equívocos por parte de estudiosos e movimentos sociais no tocante às interpretações jurídicas; dimensões da memória histórica, de reconstruções do passado e do presente, de cidadania e de direitos constitucionais podem e devem ser articulados; as narrativas, não necessariamente "verdades históricas", podem oferecer apenas um entendimento mais complexo sobre as formas camponesas do passado, da escravidão e dos anos imediatamente posteriores, no que diz respeito às conexões entre senzalas, quilombos, vilas, trocas mercantis e indígenas; investigações históricas sobre as experiências camponesas do passado podem sugerir a ampliação da definição dos quilombos históricos e das comunidades negras atuais.

Flávio dos Santos Gomes (2012, p. 393), também, argumenta que os vários significados dos quilombos e dos remanescentes podem não ser, necessariamente, uma invenção do presente, pois precisamos conhecer mais sobre as experiências ao longo do

\footnotetext{
${ }^{67}$ Não em vão, atualmente, há fortes disputas pelas terras das comunidades quilombolas, pois os quilombos se situavam geralmente em zonas férteis, próprias para o cultivo de muitas espécies vegetais, ricas em animais de caça e pesca, sendo que a utilização da terra, ao que tudo indica, tinha limites definidos, podendo-se afirmar que, a propriedade fosse comum, sendo regra a pequena propriedade em torno dos quilombos (CARNEIRO, 2011, p. XLI- XLII).
} 
século XX e antes da Constituição de 1988 e, a ressemantização alardeada como categoria antropológica não precisa excluir ou pré-selecionar experiências históricas, mas adicioná-las, considerando a existência, ou não, de registros históricos, da memória, das formas de identidade, dos aspectos do território e da cultura material.

O alerta de Flávio dos S. Gomes (2012) é interessante, porque, assim como a ressignificação e a ressemantização retiraram o essencialismo da categoria quilombo, por outro lado, parecem ter criado um novo essencialismo, ao definir a categoria apenas em seu aspecto contemporâneo relacionado aos seus processos de disputas jurídicas atuais, passaram a dar descrédito a quaisquer estudos focados aos denominados "quilombos históricos", como se estes representassem categorias "perigosas" a descontruir a própria ressignificação e ressemantização contemporânea dos quilombos.

Nesse contexto, o mais importante é saber traduzir a situação histórica de onde se originou cada experiência, quer tenha sido a partir de fugas de fazendas escravistas, confronto armado, compra de terras, doações ou ocupações, o que implica situar as falas e a significação que lhes é imprimida pelos atuais quilombolas, como também entender que a diversidade de formas de aquilombamento traduz variados estilos de busca da liberdade sob o regime escravista; assim, mesmo quando se considera como totalmente apropriada a denominação quilombos contemporâneos, tendo em vista que a expressão subentende a ideia de resgate e de atualização da experiência das comunidades que não são formações estáticas (SILVA, 2000, p. 279), evidentemente, não se precisa menosprezar os estudos da Arqueologia ${ }^{68}$ ou da História a respeito do que se denominou "quilombos históricos", pois, no campo da patrimonialidade, tais estudos são de fundamental importância para a Ciência Jurídica no âmbito dos direitos culturais e consequente afirmação da resistência quilombola ao processo de opressão da escravidão.

Com efeito, quanto à sua contemporaneidade, o uso da noção comunidades remanescentes, implica, para a população que o assume a possibilidade de ocupar um novo lugar na relação com seus vizinhos, na política local, diante dos órgãos e políticas governamentais, no imaginário nacional e, finalmente, no seu próprio imaginário; lugar a partir do qual é possível produzir um retorno com relação àquele "eixo de mutações", tratando-se de reconhecer nesses grupos, até então marginais, um valor cultural absolutamente

\footnotetext{
${ }^{68}$ Aliás, o próprio IPHAN, por longo tempo, pouca atenção deu aos sítios arqueológicos, só tendo despertado para tal questão mais recentemente. Nesse sentido, sintetizando a problemática da arqueologia nos estudos patrimoniais e dentro da estrutura do IPHAN, $c f$. BANDEIRA, Arkley M. Políticas públicas culturais e a proteção do patrimônio arqueológico no Brasil: perspectiva histórica. Revista de Políticas Públicas, vol. 22, $\mathrm{n}^{\circ}$ 1, p. 259-284, jan./jun. 2018; STANCHI, Roberto. O patrimônio arqueológico: oitenta anos de delegação. Revista do Patrimônio, no 35, p. 171-202, 2017.
} 
novo que, por ter origem em um outro quadro de referências que era até então desconhecido deles mesmos (ARRUTI, 1997, p. 22).

Outrossim, as diferenças que podiam distingui-los da população local na forma de estigmas passam a ganhar positividade, e os próprios termos "negro", "preto" ou "quilombola", muitas vezes recusados até pouco tempo antes da adoção da identidade de remanescentes, passam a ser adotados; por outro lado, as fronteiras entre quem é e quem não é da comunidade, quase sempre muito porosas, passam a ganhar rigidez e novos critérios de distinção, genealogias e parentescos horizontais passam a ser recuperados como formas de comprovação da inclusão ou não de indivíduos na coletividade; ao mesmo tempo, a maior visibilidade do grupo lhe dá uma nova posição em face das negociações políticas no âmbito municipal e, por vezes, estadual; enfim, a adoção da identidade de remanescentes por uma determinada coletividade, ainda que possa fazer referência a uma realidade comprovável, é, com muito mais força, a produção dessa própria realidade (ARRUTI, 1997, p. 23).

\section{Considerações finais}

A efetivação dos novos dispositivos da Constituição Federal de 1988, contraditando os velhos instrumentos legais de inspiração colonial, tem se deparado com imensos obstáculos, que tanto são tecidos mecanicamente nos aparatos burocráticoadministrativos do Estado, quanto são resultantes de estratégias engendradas por interesses de grupos que historicamente monopolizaram a terra, pois a efetivação dos dispositivos constitucionais relacionados a povos e comunidades tradicionais indicam que há tensões relativas ao seu reconhecimento jurídico-formal, sobretudo porque rompem com a invisibilidade social, que historicamente caracterizou estas formas de apropriação dos recursos baseadas principalmente no uso comum e em fatores culturais intrínsecos, e impelem a transformações na estrutura agrária (ALMEIDA, 2004, p. 10 e 13).

A efetivação desses dispositivos necessita, todavia, que esteja alinhada a políticas de desmascaramento do próprio racismo, sendo necessário dizer que há uma negação de direitos decorrentes do racismo que sofrem as comunidades quilombolas, seja na concretização de seus direitos culturais ou territoriais. Nesse sentido, todos os movimentos contra hegemônicos mais importantes e convincentes do presente apontam para uma direção: a necessidade de desmascarar a persistência da colônia e enfrentar-se ao significado político da raça como princípio capaz de desestabilizar a estrutura profunda da colonialidade, 
percebendo a raça do continente, nomeando-a, é uma estratégia da luta essencial no caminho da descolonização (SEGATO, 2010, p. 20).

Falar de racismo constitui um tabu porque toca a sensibilidade de vários atores entronizados, que vão desde a esquerda tradicional e acadêmica (já que implica dar carne e osso para a matemática das classes, introduzindo cor, cultura e história própria não eurocêntrica e, em suma, diferença), sociológica (porque os números sobre esse tema são escassos e muito difíceis de precisar com objetividade, devido às complexidades da classificação racial na América Latina), e, por fim, toca a sensibilidade dos jurista e das forças da lei (porque sugere um racismo estatal); além disso, falar de racismo implica iniciar uma nova época nas propostas políticas, que tenderão ser corrigidas, com a devolução da consciência histórica daqueles que foram dela expropriados e que hoje vivem em uma espécie de orfandade genealógica (SEGATO, 2010, p. 21-22).

Superar esse tabu que impede se falar de racismo é uma premissa para tratar dos direitos quilombolas. O racismo necessita ser desmascarado, a fim de que a lógica de negação dos direitos seja rompida e quebrada. Nesse sentido, o reconhecimento da patrimonialidade quilombola evidencia que as lutas contra a escravidão e o racismo permanecem, não podendo mais ser ocultadas em uma narrativa que embranqueceu a história nacional e usou a cultura negra apenas quando foi conveniente para os usos do mercado, em espécie de antropofagia estética ou canibalismo cultural $^{69}$ (CARVALHO, 2004, p. 7) ou para a afirmação do EstadoNação, através do mito fundacional da democracia racial ou da doçura da mestiçagem, como evidenciou Peter Wade (2003, p. 154), ao analisar a apropriação de elementos da cultura negra na Colômbia, em algo muito similar ao que ocorreu no Brasil, com o samba ou a capoeira:

Há aí dois aspectos a destacar. Primeiro, a ideologia nacionalista da mestiçagem implica, automaticamente, os troncos nocionais originais envolvidos na criação da nação mestiça - africanos, índios americanos, europeus - e, por conseguinte, reafirma a existência deles, ao mesmo tempo em que contempla seu eventual desaparecimento.

Entretanto, a eliminação completa dessas origens ameaça roubar do país sua auto definição como mestiço: sem a presença dos ingredientes originais, o processo contínuo de mistura perde o sentido. A ideologia da mestiçagem implica uma mescla contínua, assim como uma separação contínua. Em

\footnotetext{
${ }^{69}$ José Jorge de Carvalho (2004, p. 7) diz que o lema antropofágico funciona como uma espécie de código secreto da impunidade estética e da manutenção de privilégios da classe dominante brasileira, que se apropria dos elementos culturais de comunidades e artistas indígenas e afro-brasileiros, em uma suposta síntese cultural modernista (os tais empréstimos culturais que, com o passar do tempo, se tornam roubo) e que propõe e executa os inventários do patrimônio cultural imaterial brasileiro sem politizar a retirada do Estado em favor dos empreendedores interessados em mercantilizar, sem nenhum compromisso de continuidade, essas mesmas tradições performáticas (CARVALHO, 2004, p. 7).
} 
segundo lugar, a ênfase constante na diferença racial é central para a definição das elites como superiores - mais brancas, mais ricas, mais centrais, mais "civilizadas", mais "modernas", e assim por diante. Os negros e índios são não apenas identificados como racialmente distintos, mas também frequentemente associados à pobreza, à marginalidade, à vulgaridade e ao atraso (WADE, 2003, p. 154).

Note-se que pobreza, marginalidade, vulgaridade e atraso são associações adjetivas atribuídas costumeiramente às comunidades quilombolas nos discursos econômicos, sociais, políticos e jurídicos que tentam deslegitimar a sua contemporaneidade, o reconhecimento e a inclusão de seus direitos e patrimônios. Como contraponto a isso, a Constituição Federal já previu que a memória, a história e a patrimonialidade quilombola devem ser evidenciadas, saindo do ocultamento/silenciamento/esquecimento o qual foi submetido por mais de um século.

O que a patrimonialidade quilombola sugere é evidenciar que as lutas contra a opressão dos direitos negados são questões ainda presentes: se no passado a liberdade, em seu sentido mais restrito, era o direito a ser alcançado, na atualidade, a igualdade, a inclusão e o respeito às diferenças constituem os novos objetivos.

Nesse sentido, Alfredo Wagner Berno de Almeida (2005b, p. 2) alerta que o conhecimento da tradicionalidade quilombola possui uma politização e é por isso que esse simbólico deixa de ser um patrimônio meramente intangível e passa a ser um patrimônio que constitui um capital de relações políticas e o advento da identidade coletiva desperta a atenção para um novo padrão de relação política que está surgindo na sociedade brasileira (ALMEIDA, 2005b, p. 2), decorrentes da lutas e (re)existências quilombolas.

\section{Referenciais Bibliográficos}

AGIER, Michel. La antropologia de las identidades en las tensiones contemporâneas. Revista Colombiana de Antropología, Bogotá, vol. 36, p. 6-17, ene./dic. 2000.

AGIER, Michel. Distúrbios identitários em tempos de globalização. Mana: estudos de Antropologia Social, Rio de Janeiro (Museu Nacional/UFRJ), vol. 7, nº 2, p. 7-33, 2001.

AGIER, Michel; QUINTÍN, Pedro. Política, cultura y autopercepción: las identidades en cuestión. Estudos Afro-Asiáticos, Rio de Janeiro (UCAM), ano 25, nº 1, p. 23-41, 2003.

ALMEIDA, Alfredo Wagner Berno de. Os quilombos e as novas etnias. In: O'DWYER, Eliane Cantarino (org.). Quilombos: identidade étnica e territorialidade. Rio de Janeiro: Editora FGV, 2002, p. 43-81. 
ALMEIDA, Alfredo Wagner Berno de. Terras tradicionalmente ocupadas. Processos de territorialização e movimentos sociais. Revista Brasileira de Estudos Urbanos e Regionais, São Paulo, vol. 6, nº 1, p. 9-32, maio 2004.

ALMEIDA, Alfredo Wagner de. Conceito de terras tradicionalmente ocupadas: palestra no seminário sobre questões indígenas. Revista da AGU, Brasília, ano 4, nº 8, p. 1-10, set./dez. 2005b.

ALMEIDA, Alfredo Wagner Berno de et. al. (org.). Quilombolas: reivindicações e judicialização dos conflitos. Manaus: Projeto Nova Cartografia Social da Amazonia/UEA Edições, 2012.

ALMEIDA, Alfredo Wagner Berno de; ANJOS, Leonardo dos et. al. (orgs.). Direitos e mobilização: a luta dos quilombolas de Alcântara contra a base espacial. Rio de Janeiro: Casa 8, 2016.

ANDRADE, Manuel Correia de. Geografia do quilombo. In: MOURA, Clóvis (org.). Os quilombos na dinâmica social do Brasil. Maceió: EDUFAL, 2001, p. 75-87.

ÁNGELES QUEROL, María. Manual de gestión del patrimonio cultural. Madrid: Akal, 2010 .

ANJOS, Rafael Sanzio Araújo dos. Cartografia da diáspora África-Brasil. Revista da ANPEGE: Associação Nacional de Pesquisa e Pós-Graduação em Geografia, vol. 7, nº 1, p. 261-274, out. 2011.

ARRUTI, José Maurício Andion. A emergência dos "remanescentes": notas para o diálogo entre indígenas e quilombolas. Mana: estudos de antropologia social, Rio de Janeiro (Museu Nacional/UFRJ), vol. 3, nº 02, p. 7-38, 1997.

ARRUTI, José Maurício Andion. As comunidades negras rurais e suas terras: a disputa em torno de conceitos e números. Dimensões (Departamento de História da UFES), vol. 14, p. 243-267, 2002.

BANDEIRA, Arkley Marques. Políticas públicas culturais e a proteção do patrimônio arqueológico no Brasil: perspectiva histórica. Revista de Políticas Públicas, São Luís (UFMA), vol. 22, nº 1, p. 259-284, jan./jun. 2018.

BENATTI, José Heder et. al. Populações tradicionais e o reconhecimento de seus territórios: uma luta sem fim. Anais do $7^{\circ}$ Encontro Nacional da Associação Nacional de PósGraduação e Pesquisa em Ambiente e Sociedade - ANPPAS, p. 1-19, 2015.

BORBA, Fernanda Mara. Entre reminiscências e remanescente: a presença e a ausência do passado em torno do quilombo no Brasil. Anais do III Seminário Internacional História do tempo presente, Universidade do Estado de Santa Catarina - UDESC, Florianópolis, p. 1-13, 2017.

CAMPOS, Yuseff Daibert Salomão de. Desafios propostos pela Constituição de 1988 ao patrimônio cultural. Revista do Patrimônio Histórico e Artístico Nacional, Brasília (IPHAN), n 35, p. 203-212, 2017. 
CARNEIRO, Edison. O Quilombo dos Palmares. Prefácio de Flávio dos Santos Gomes. 5. ed. São Paulo: Martins Fontes, 2011.

CARVALHO, José Jorge de. Metamorfoses das tradições performáticas afro-brasileiras: do patrimônio cultural a indústria de entretenimento. Série Antropologia, Brasília (UnB), n ${ }^{\circ}$ 354, p. 1- 21, 2004.

CHUVA, Márcia Regina Romeiro. Fundando a nação: a representação de um Brasil barroco, moderno e civilizado. Topoi, Rio de Janeiro (UFRJ), vol. 4, nº 7, p. 313-333, jul./dez. 2003.

COELHO, Leonardo Oliveira Silva. Terras de sustança: resistência quilombola e estratégias de reapropriação de território em Alcântara. São Luís: EDUFMA, 2017.

COLOMBATO, Lucía Carolina; MEDICI, Alejandro Marcelo. El derecho humano a los patrimonios culturales em clave decolonial. RBSD - Revista Brasileira de Sociologia do Direito, Recife (ABraSD), vol. 3, nº 3, p. 67-95, set./dez. 2016.

CUNHA, Felipe Gibson; ALBANO, Sebastião G. Identidades quilombolas: políticas, dispositivos e etnogêneses. LatinoAmérica: Revista de Estudios Latinoamericanos, México (UNAM), vol. 64, nº 01, p. 153-184, 2017.

DE LA SERNA, Juan Manuel. Los cimarrones en la sociedade novohispana. In: DE LA SERNA, Juan Manuel (Coord.) De la libertad y la abolición: africanos y afrodescendentes en Iberoamérica. México: Instituto Nacional de Antropología e Historia - INAH, 2010, p. 83109.

FIABANI, Adelmir. O quilombo antigo e o quilombo contemporâneo: verdades e construções. Anais do XXIV Simpósio Nacional de História da Associação Nacional de História - ANPUH, p. 1-10, 2007.

FISCHER, Brodwyn; GRINBERG, Keila; MATTOS, Hebe. Direito, silêncio e racialização das desigualdades na história afro-brasileira. In: ANDREWS, George Reid; DE LA FUENTE, Alejandro (orgs.). Estudos afro-latino-americanos: uma introdução. Tradução de Mariângela de Mattos Nogueira e Fábio Baqueiro Figueiredo. Buenos Aires:

CLACSO/Harvard University, 2018, p. 163-215.

GOMES, Flávio dos Santos. "No labirinto dos rios, furos e igarapés": camponeses negros, memória e pós-emancipação na Amazônia, c. XIX-XX. História Unisinos, vol. 10, n 3, p. 281-292, set./dez. 2006.

GOMES, Flávio Santos. Terra e camponeses negros: o legado da pós-emancipação. Revista do Patrimônio Histórico e Artístico Nacional, vol. 34 [dossiê História e Patrimônio], p. 375-395, 2012.

GURAN, Milton. Sobre o longo percurso da matriz africana pelo seu reconhecimento patrimonial como uma condição para a plena cidadania. Revista do Patrimônio Histórico e Artístico Nacional, Brasília (IPHAN), nº 35, p. 213-226, 2017.

IPHAN - Instituto do Patrimônio Histórico e Artístico Nacional. Processo no 1.069-T-82. Tombamento da Serra da Barriga (Quilombo dos Palmares), União dos Palmares/AL. Brasília: 1982b. 
IPHAN - Instituto do Patrimônio Histórico e Artístico Nacional. Processo no 1.428-T-98. Tombamento das reminiscências históricas do antigo Quilombo do Ambrósio, Ibiá/MG. Brasília: 1998c.

LAO-MONTES, Agustín. Sin justicia étnico-racial no hay paz: las afro-reparaciones en perspectiva histórico-mundial. In: MOSQUERA ROSERO-LABBÉ, Claudia; BARCELOS, Luiz Claudio (org.). Afro-reparaciones: memorias de la esclavitud y justicia reparativa para negros, afrocolombianos y raizales. Bogotá: Universidad Nacional de Colombia - UNAL, 2007, p. 131-152.

LINDOSO, Dirceu. A razão quilombola: estudos em torno do conceito quilombola de nação etnográfica. Maceió: EDUFAL, 2011.

MACARRÓN MIGUEL, Ana María. Conservación del patrimonio cultural: criterios y normativas. Madrid: Síntesis, 2008.

MATTOS, Hebe Maria. Ciudadanía, racialización y memoria del cautiverio en la historia de Brasil. In: MOSQUERA ROSERO-LABBÉ, Claudia; BARCELOS, Luiz Claudio (org.).

Afro-reparaciones: memorias de la esclavitud y justicia reparativa para negros, afrocolombianos y raizales. Bogotá: UNAL, 2007, p. 131-152.

MARQUES, Carlos Eduardo. De quilombos a quilombolas: notas sobre um processo histórico-etnográfico. Revista de Antropologia, São Paulo (USP), vol. 52, nº 1, p. 339-374, 2009.

MARQUES, Carlos Eduardo; GOMES, Lílian. A Constituição de 1988 e a ressignificação dos quilombos contemporâneos. Revista Brasileira de Ciência Sociais, vol. 28, nº 81, p. 137-255, fev. 2013.

MOSQUERA ROSERO-LABBÉ, Claudia; LAÓ-MONTES, Agustín; RODRÍGUEZ GARAVITO, César (Coords.). Debates sobre ciudadanía y políticas raciales en las Américas Negras. Bogotá: Universidad Nacional de Colombia - UNAL, 2010.

MOURA, Clóvis. Os quilombos e a rebelião negra. São Paulo: Brasiliense, 1981.

MOURA, Clóvis. Quilombos: resistência ao escravismo. 3. ed. São Paulo: Editora Ática, 1993.

NASCIMENTO, Beatriz. Kilombo e memória comunitária: um estudo de caso. In: RATTS, Alex. Eu sou atlântica: sobre a trajetória de vida de Beatriz Nascimento. São Paulo: Instituto Kuanza/Imprensa Oficial, 2006, p. 109-125.

PEREIRA, Paulo Fernando Soares. Os esquecimentos da memória: o tombamento do patrimônio cultural quilombola e a formulação de uma política pública. Tese (Doutorado em Direito), Universidade de Brasília - UnB, 2019, 350 f.

Os Quilombos e a Nação: inclusão constitucional, políticas públicas e antirracismo patrimonial. Rio de Janeiro: Lumen Juris, 2020. 
PRICE, Richard. Reinventando a história dos quilombos: rasuras e confabulações. AfroÁsia, no 23, p. 1-26, 1999 b.

PRICE, Richard. O milagre da crioulização: retrospectiva. Estudos Afro-Asiáticos, ano 25, no 3, p. 383-419, 2003.

REIS, João José. Quilombos e revoltas escravas no Brasil: "Nos achamos em campo a tratar a liberdade". Revista USP, São Paulo, vol. 28, p. 14-39, dez./fev. 95/96.

RODRÍGUEZ GARAVITO, César; LAM, Yukyan. Etnorreparaciones: La justicia colectiva étnica y la reparación a pueblos indígenas y comunidades afrodescendentes en Colombia.

Bogotá: Dejusticia, 2011.

SANTANA FILHO, Diosmar Marcelino de. A geopolítica do Estado e o território quilombola no século XXI. Jundiaí: Paco Editorial, 2018.

SANTOS, Joel Rufino dos. Saber do negro. Rio de Janeiro: Pallas, 2015.

SANTOS, Ynaê Lopes dos. História da África e do Brasil afrodescendente. Rio de Janeiro: Pallas, 2017.

SEGATO, Rita Laura. Los cauces profundos de la raza latinoamericana: una relectura del mestizaje. Crítica y Emancipación: Revista Latinoamericana de Ciencias Sociales, Buenos Aires (CLASCO), vol. 3, p. 11-44, jan./jun. 2010.

SEGATO, Rita Laura. Gênero e colonialidade: em busca de chaves de leitura e de um vocabulário descolonial. E-cadernos CES [On-line], Epistemologias feministas: ao encontro da crítica radical, Coimbra (Universidade de Coimbra), nº 18, p. 106-131, 2012.

SERRA, Ordep. Monumentos negros: uma experiência. Afro-Ásia, Salvador (UFBA), no 33, p. 169-205, 2005.

SHIRAISHI NETO, Joaquim. A particularização do universal: povos e comunidades tradicionais face às declarações e convenções internacionais. In:

Direitos dos

povos e das comunidades tradicionais no Brasil: declarações, convenções, internacionais e dispositivos jurídicos definidores de uma política nacional. Manaus: UEA Edições, 2007, p. 25-52.

SILVA, Valdélio Santos. Rio das Rãs à luz da noção de quilombo. Afro-Ásia, no 23, p. 265293, 2000.

SINGLETON, Theresa A. Reflexões sobre a arqueologia da diáspora africana no Brasil. Vestígios: Revista Latino-Americana de Arqueologia Histórica, Belo Horizonte (UFMG), vol. 7, no 1, p. 211-219, jan./jun. 2013.

SIQUEIRA, José Jorge. Pós-Abolição, intelectuais negros e projeto de Brasil: notas de um estudo. Revista da ABPN: Associação Brasileira de Pesquisadoras(es) Negras(os), Uberlândia, vol. 10, nº 25, p. 82-100, mar./jun. 2018. 
SOUSA, José Reinaldo Miranda de. Quilombos (palenques), terras de pretos: identidades em construção. Revista Brasileira do Caribe, São Luís (UFMA), vol. XI, nº 22, p. 33-57, jan./jun. 2011.

SOUZA FILHO, Benedito. Os novos capitães do mato: conflitos e disputa territorial em Alcântara. São Luís: EDUFMA, 2013.

SOUZA, Marcos André Torres de. Introdução: arqueologia da diáspora africana no Brasil. Vestígios: Revista Latino-Americana de Arqueologia Histórica, Belo Horizonte (UFMG), vol. 7, no 1, p. 9-19, jan./jun. 2013.

STANCHI, Roberto. O patrimônio arqueológico: oitenta anos de delegação. Revista do Patrimônio Histórico e Artístico Nacional, nº 35, p. 171-202, 2017.

VAZ, Beatriz Aciolly. Os grilhões do patrimônio: reflexões sobre as práticas do IPHAN relacionadas aos quilombos. Revista CPC: Centro de Preservação Cultural, São Paulo (USP), n 17, p. 35-46, nov. 2013/abr. 2014.

WADE, Peter. Compreendendo a "África" e a "negritude" na Colômbia: a música e a política da cultura. Estudos Afro-Asiáticos, Rio de Janeiro (UCAM), ano 25, nº 1, p. 145-178, 2003.

Data de recebimento: 03.06.2020

Data de aprovação: 08.08.2020 